ARTICLE

\title{
Asymmetric biomimetic transamination of $\alpha$-keto amides to peptides
}

Weiqi Cai ${ }^{1,2}$, Xuelong Qiao ${ }^{1,2}$, Hao Zhang ${ }^{1}$, Bo Li (10 ${ }^{1}$, Jianhua Guo ${ }^{1}$, Liangliang Zhang ${ }^{1}$, Wen-Wen Chen ${ }^{1}$ \& Baoguo Zhao (1) ${ }^{1 \times}$

Peptides are important compounds with broad applications in many areas. Asymmetric transamination of $\alpha$-keto amides can provide an efficient strategy to synthesize peptides, however, the process has not been well developed yet and still remains a great challenge in both enzymatic and catalytic chemistry. For biological transamination, the high activity is attributed to manifold structural and electronic factors of transaminases. Based on the concept of multiple imitation of transaminases, here we report $\mathrm{N}$-quaternized axially chiral pyridoxamines $\mathbf{1}$ for enantioselective transamination of $\alpha$-keto amides, to produce various peptides in good yields with excellent enantio- and diastereoselectivities. The reaction is especially attractive for the synthesis of peptides made of unnatural amino acids since it doesn't need great efforts to make chiral unnatural amino acids before amide bond formation.

\footnotetext{
${ }^{1}$ The Education Ministry Key Lab of Resource Chemistry and Shanghai Key Laboratory of Rare Earth Functional Materials, Shanghai Normal University, Shanghai, P. R. China. ${ }^{2}$ These authors contributed equally: Weiqi Cai, Xuelong Qiao. ${ }^{凶}$ email: zhaobg2006@shnu.edu.cn
} 
eptides are one type of the most important compounds with high biological activities, which are widely present in many natural products, pharmaceutically relevant molecules, and biological systems ${ }^{1-3}$. Especially in recent years, there appears a growing interest in therapeutic peptides ${ }^{1-3}$ and more and more peptide drugs have been developed (Fig. 1a) ${ }^{4-6}$. Development of alternative new methods for the synthesis of peptides is always highly desirable and potentially useful ${ }^{7,8}$.

Enzymatic transamination is an important process to produce chiral amines such as amino acids in biological systems (Fig. 1b) $)^{9,10}$, which is promoted by transaminases (Fig. 1c) with pyridoxal/pyridoxamine $5^{\prime}$-phosphates as the coenzyme ${ }^{9-13}$. Mimicking the biological process ${ }^{14}$, i.e., asymmetric biomimetic transamination, affords

a<smiles>COC(=O)N[C@H](C(=O)N[C@H](Cc1ccccc1)[C@@H](O)CN(Cc1ccc(-c2ccccn2)cc1)NC(=O)[C@@H](NC(=O)OC)C(C)(C)C)C(C)(C)C</smiles><smiles>CC(C)CC(NC(=O)C(CCc1ccccc1)NC(=O)CN1CCOCC1)C(=O)NC(Cc1ccccc1)C(=O)NC(CC(C)C)C(=O)C(C)(C)O</smiles><smiles>CC(=O)CNC(=O)N1CCCN1C(=O)C(CCCCNC(C)C)NC(=O)C(CC(C)C)NC(=O)C(CC(N)=O)NC(=O)C(Cc1ccc(O)cc1)N(C)C(=O)[C@H](CO)NC(=O)[C@H](Cc1cccnc1)NC(=O)C(Cc1ccc(Cl)cc1)NC(=O)[C@H](Cc1ccc2ccccc2c1)NC(C)=O</smiles>

b

Biological transamination

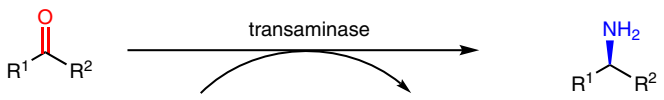<smiles></smiles><smiles></smiles>

pyridoxamine $5^{\prime}$-phosphate (PMP)<smiles>[R]C([R])=O</smiles>

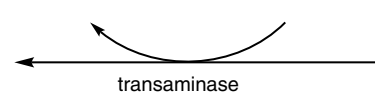

$$
\text { amine donor }_{\mathrm{R}^{4}}^{\mathrm{NH}_{2}}
$$

C Transaminase and bioinspired pyridoxamine catalyst

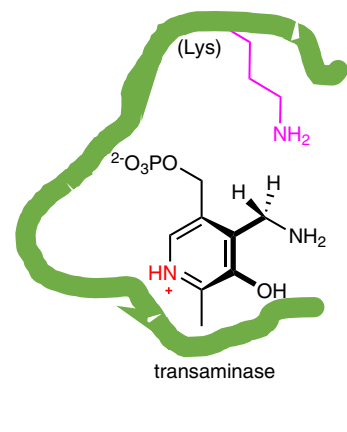

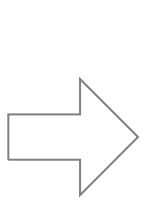

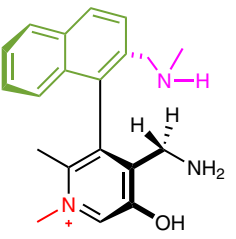

1

\section{d}

The key step of biological transamination: asymmetric 1,3-proton shift<smiles>[R6]OCc1c[nH+]c(C)c(O)c1[C@@H](N=C([R])[R])c1ccccc1</smiles>
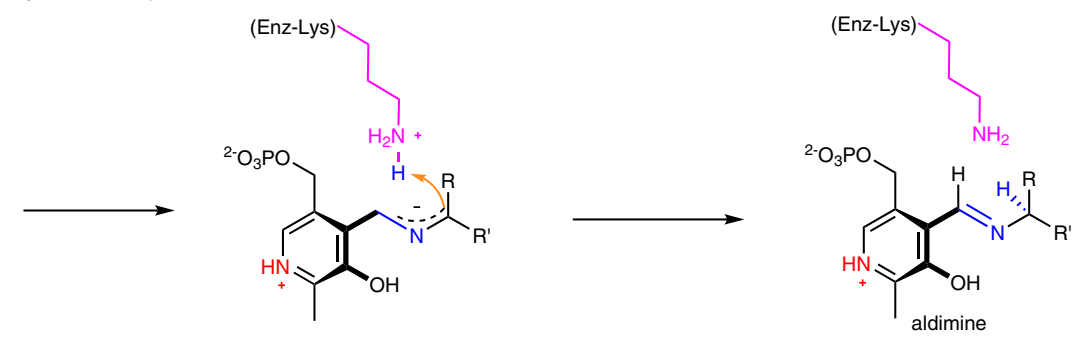

Asymmetric biomimetic transamination of $\alpha$-keto amides to peptides<smiles>[R]OC(=O)C([R7])NC(=O)[C@H]([PH])NC(=O)C([R])=O</smiles>
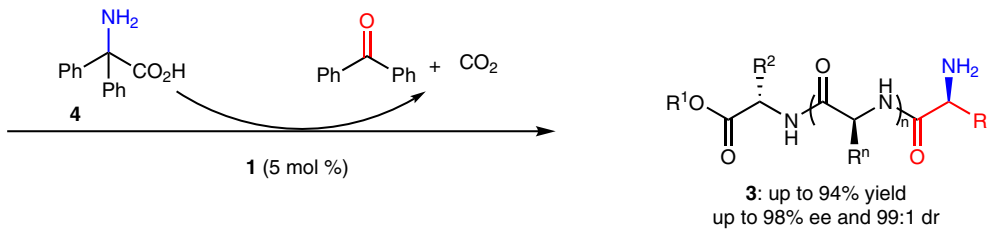

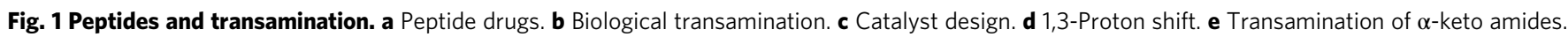




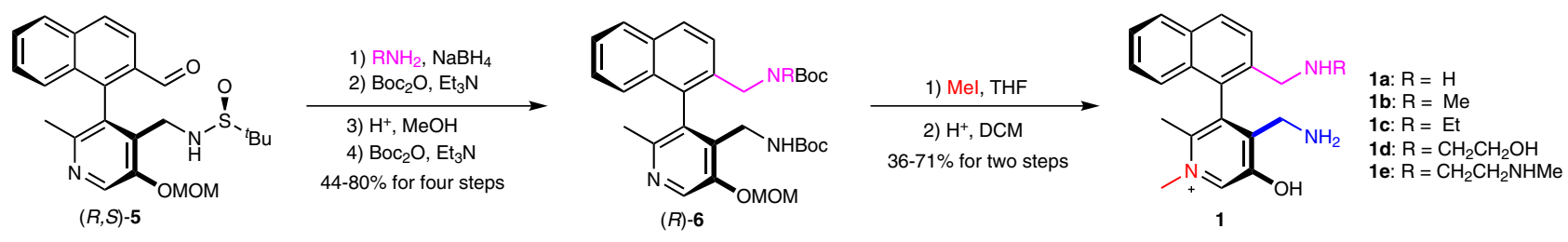

Fig. 2 Synthesis chiral pyridoxamines 1. The detailed synthetic procedures have been presented in Supplementary Information (SI). THF = tetrahydrofuran, DCM = dichloromethane.

a highly intriguing method to synthesize $\mathrm{NH}_{2}$-free amines from readily available carbonyl compounds ${ }^{15-17}$. The chemistry has attracted much attention since the $1970 \mathrm{~s}^{18-36}$. The studies mainly include stoichiometric chiral pyridoxamine-promoted asymmetric transamination of $a$-keto acids ${ }^{18-21}$, pyridoxal/pyridoxamine-catalyzed asymmetric transamination of $a$-keto acids ${ }^{22-26}$, and chiral base/Lewis acid-catalyzed asymmetric transamination of $\alpha$-keto esters and activated ketones ${ }^{27-36}$. Asymmetric transamination of a-keto amides can potentially provide an appealing new strategy to produce peptides. However, to the best of our knowledge, asymmetric transamination of $\alpha$-keto amides to peptides are barely reported ${ }^{37,38}$, although the reverse process, transamination of peptides at the $\mathrm{N}$-termini to a-keto amides, has been widely developed and already have been successfully applied to protein modification ${ }^{38-45}$. In contrast to the transamination of $\alpha$-keto acids, asymmetric transamination of $a$-keto amides to peptides remains a challenge for enzymatic catalysis likely due to non-naturally occurring process and it is also a challenge for chemical catalysis probably because the complicated structure of $\alpha$-keto amides requires more active catalysts to promote transamination.

Previous studies have suggested that asymmetric 1,3-proton shift between the ketimine intermediate and the aldimine is likely a key step for biological transamination (Fig. 1d) ${ }^{11-13,46,47}$. In order to accelerate this step, evolution has elegantly optimized transaminases by incorporating a Lys residue at an appropriate position ${ }^{48-50}$. The $\varepsilon$ $\mathrm{NH}_{2}$ group of the Lys residue serves as an intramolecular base to deprotonate the benzylic $\mathrm{C}-\mathrm{H}$ of the ketimine (Fig. 1d) ${ }^{48-50}$. In addition, the $\mathrm{p} K_{\mathrm{a}}$ values of the pyridine $\mathrm{N}$ in the coenzyme pyridoxal $5^{\prime}$-phosphate (PLP) and pyridoxamine 5'-phosphate (PMP) are around $8.5^{51-53}$, thus the pyridine $\mathrm{N}$ is predominantly protonated in biological systems (near $\mathrm{pH} 7)^{53-56}$. The strong electron-withdrawing property of the protonated pyridine ring helps to increase the acidity of the benzylic C-H bond (Fig. 1d) ${ }^{54-58}$. The two effects work together to promote the transformation from the ketimine to the aldimine via 1,3-proton shift, magically accelerating transamination process. Inspired by the controlled protonation of the pyridine $\mathrm{N}$ of PLP in biological systems, Rapoport has developed $N$-methylpyridinium-4-carboxaldehyde benzenesulfonate (Rapoport's salt) as an effective transamination reagent for conversion of amines to carbonyl compounds ${ }^{59}$. Francis have found that Rapoport's salt displays significantly improved efficiency in the transamination of proteins as compared to pyridinium-4-carboxaldehyde, converting the N-termini into the corresponding carbonyl groups ${ }^{44,45}$. Recently, we have proved that introducing an amine side arm to a chiral pyridoxamine can remarkably increase its activity and enantioselectivity for asymmetric transamination of $a$-keto acids ${ }^{26}$ and also have observed that quaternization of the pyridine $\mathrm{N}$ of a chiral pyridoxal leads to dramatical improvement of catalytic activity for asymmetric biomimetic Mannich reaction ${ }^{60}$ and aldol reaction ${ }^{61}$ of glycinate. On the basis of the structural characteristics of transaminases ${ }^{46-50,53-56}$ as well as the previously reported studies $26,44,45,59-62$, we has designed $\mathrm{N}$-quaternized biaryl axially chiral pyridoxamines $\mathbf{1}$ bearing an amine side arm, mimicking transaminases in multiple aspects for catalytic asymmetric transamination of a-keto amides to peptides (Fig. 1c). The quaternization always keeps the pyridine ring with strong electron-withdrawing ability to improve the benzylic C-H acidity of the ketimine intermediate during transamination, no matter under acidic or basic conditions ${ }^{60,61}$. Like the Lys residue does in biological transamination, the amine side arm can serve as an intramolecular base to facilitate 1,3-proton shift.

Here we show that asymmetric biomimetic transamination of a-keto amides 2 can be achieved by using chiral pyridoxamines 1 as the catalyst, to produce various peptides $\mathbf{3}$ with excellent enantiopurities (Fig. 1e).

\section{Results}

Catalyst synthesis. The synthesis of chiral pyridoxamines 1 started with reductive amination of compound $5^{26}$ to introduce the amine side chain. Protecting the two amine groups with ditert-butyl dicarbonate gave intermediates 6 (Fig. 2). Treatment of 6 with methyl iodide and subsequent deprotection with hydrochloric acid afforded $N$-methyl pyridoxamines 1a-e in good yields.

Condition optimization. With diphenylglycine (4) as the amine source $25,26,63$, catalyst chiral pyridoxamine $\mathbf{1 b}$ was first tested for the transamination of glycinyl a-keto amide $2 \mathbf{a}$ (Fig. 3, entry 1). The originally-formed $\mathrm{NH}_{2}$-free transamination product was treated with di-tert-butyl dicarbonate to avoid the cyclization to piperazinedione during the isolation ${ }^{64}$, to give the corresponding $N$-Boc-protected dipeptide 3 a in $20 \%$ yield with $76 \%$ ee. Additives have significant impacts on the reaction in terms of enantioselectivity and activity. Increased yield and enantioselectivity were obtained for transaminations performed in $\mathrm{MeOH} / \mathrm{H}_{2} \mathrm{O}$ or TFEA $/ \mathrm{H}_{2} \mathrm{O}$ with $\mathrm{HOAc} / \mathrm{KOAc}$ or $\mathrm{HOAc} / \mathrm{Na}_{2} \mathrm{HPO}_{4}$ as the additives (Fig. 3, entries 2 and 10 vs 3-9). Chiral pyridoxamine $\mathbf{1 b}$ exhibited the best performance among the catalysts 1a-e examined (Fig. 3, entries 10-14).

Substrate scope. Under the optimal conditions, various glycinyl a-keto amides containing alkyl (for $\mathbf{3 b}$-e), aromatic (for $\mathbf{3 a}$ and $\mathbf{3 f}-\mathbf{i}$ ), or heteroatomic alkyl (for $\mathbf{3 j - k}$ ) groups were all smoothly transaminated to give the corresponding $N$-Boc-protected glycinyl dipeptides 3a-k in 70-94\% yields with up to $98 \%$ ee (Fig. 4). Chiral glycinyl a-keto amide (for 31 ) displayed excellent diastereoselectivity (98:2 dr). Transamination of a-keto phenylbutanamides of chiral amino acid esters produced various $\mathrm{N}$-Bocprotected dipeptides $3 \mathbf{m}-\mathbf{y}$ in $56-93 \%$ yields with up to $99: 1$ diastereoselectivity. Peptidyl $a$-keto amides were also effective for the asymmetric transamination, to form tripeptides $\mathbf{3 z}$-ab and tetrapeptides 3ac-ad in $60-87 \%$ yields with excellent diastereoselectivities under very mild conditions. Various functional groups such as $\mathrm{C}-\mathrm{C}$ double bond (for $3 \mathrm{c}, 3 \mathrm{l}$ and $\mathbf{3 y}$ ), $\mathrm{NH}_{2}$-sensitive bromide (for $\mathbf{3} \mathbf{j}$ ), silyl group (for $\mathbf{3 k}$ ), $\mathrm{OH}$ group of Tyr (for $\mathbf{3} \mathbf{s}$ ), $\mathrm{NH}$ group of Trp (for 3t), amide $\mathrm{CONH}_{2}$ of Asn (for $3 \mathbf{v}$ ), Bocprotected Lys residue (for $\mathbf{3 w}$ ), Boc-protected guanidine (for $\mathbf{3 x}$ ), and basic $\mathrm{NH}_{2}$ group of Lys (for 3ab) were all well tolerated by the transamination likely due to the mild reaction conditions.

In order to investigate the impacts of catalyst and substrates on diastereomeric induction, several representative a-keto amides (for $3 \mathbf{m}-\mathbf{n}, 3 \mathbf{r}, 3 \mathbf{v}-\mathbf{y}$, and $\mathbf{3 a a}-\mathbf{a b})$ were examined respectively using $(S)$ - 


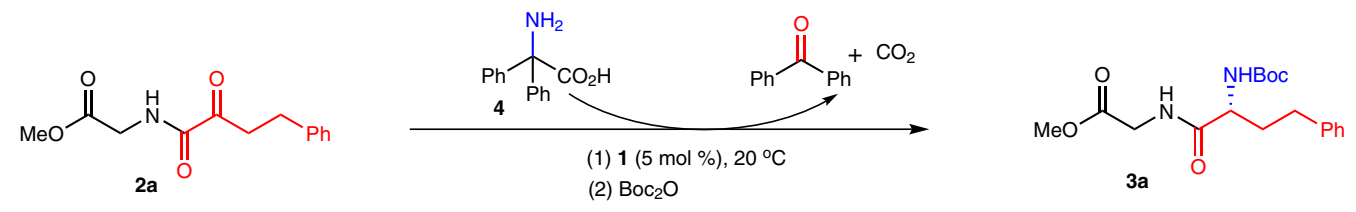

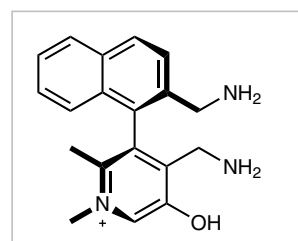

(S)-1a

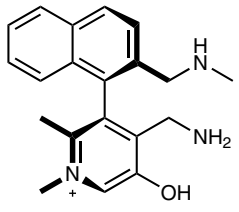

(S) $-\mathbf{1 b}$

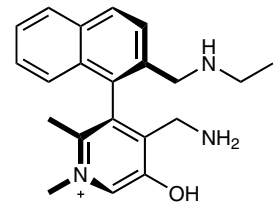

(S)-1c

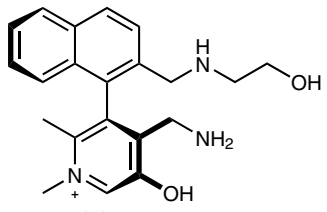

$(R)-1 \mathbf{d}$

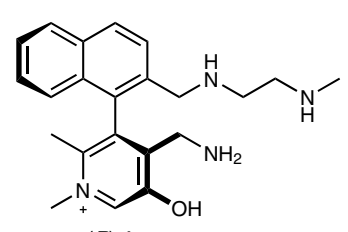

$(R)-1 \mathrm{e}$

\begin{tabular}{|c|c|c|c|}
\hline Entry & Reaction conditions & Yield $(\%)^{\mathbf{b}}$ & ee $(\%)^{c}$ \\
\hline 1 & $(S)-\mathbf{1 b}, \mathrm{MeOH} / \mathrm{H}_{2} \mathrm{O}$ & 20 & 76 \\
\hline 2 & (S)-1b, $\mathrm{HOAc} / \mathrm{KOAc}, \mathrm{MeOH} / \mathrm{H}_{2} \mathrm{O}$ & 88 & 93 \\
\hline 3 & (S)-1b, $\mathrm{HOAc} / \mathrm{KOAc}, \mathrm{THF} / \mathrm{H}_{2} \mathrm{O}$ & 21 & 84 \\
\hline 4 & (S)-1b, $\mathrm{HOAc} / \mathrm{KOAc}, \mathrm{CH}_{3} \mathrm{CN} / \mathrm{H}_{2} \mathrm{O}$ & 49 & 67 \\
\hline 5 & (S)-1b, $\mathrm{HOAc} / \mathrm{KOAc}, \mathrm{DCM} / \mathrm{H}_{2} \mathrm{O}$ & 29 & 80 \\
\hline 6 & (S)-1b, $\mathrm{HOAc} / \mathrm{KOAc}, \mathrm{TFEA} / \mathrm{H}_{2} \mathrm{O}$ & 77 & 95 \\
\hline 7 & $(S)-\mathbf{1 b}, \mathrm{HOAc} / \mathrm{NaHCO}_{3}, \mathrm{MeOH} / \mathrm{H}_{2} \mathrm{O}$ & 29 & 89 \\
\hline 8 & (S)-1b, $\mathrm{HOAc} / \mathrm{Na}_{2} \mathrm{HPO}_{4}, \mathrm{MeOH} / \mathrm{H}_{2} \mathrm{O}$ & 88 & 95 \\
\hline 9 & (S)-1b, $\mathrm{HOAc} / \mathrm{Et}_{3} \mathrm{~N}, \mathrm{MeOH} / \mathrm{H}_{2} \mathrm{O}$ & 66 & 89 \\
\hline $10^{d}$ & (S)-1b, $\mathrm{HOAc} / \mathrm{Na}_{2} \mathrm{HPO}_{4}, \mathrm{TFEA} / \mathrm{H}_{2} \mathrm{O}$ & 88 & 98 \\
\hline $11^{d}$ & (S)-1a, $\mathrm{HOAc} / \mathrm{Na}_{2} \mathrm{HPO}_{4}, \mathrm{TFEA} / \mathrm{H}_{2} \mathrm{O}$ & 77 & 77 \\
\hline $12^{d}$ & (S)-1c, $\mathrm{HOAc} / \mathrm{Na}_{2} \mathrm{HPO}_{4}, \mathrm{TFEA} / \mathrm{H}_{2} \mathrm{O}$ & 86 & 92 \\
\hline $13^{d}$ & $(R)-1 \mathrm{~d}, \mathrm{HOAc} / \mathrm{Na}_{2} \mathrm{HPO}_{4}, \mathrm{TFEA} / \mathrm{H}_{2} \mathrm{O}$ & 57 & -84 \\
\hline $14^{d}$ & (R)-1e, $\mathrm{HOAc} / \mathrm{Na}_{2} \mathrm{HPO}_{4}, \mathrm{TFEA} / \mathrm{H}_{2} \mathrm{O}$ & 80 & -85 \\
\hline
\end{tabular}

Fig. 3 Investigation of reaction parameters. TFEA =2,2,2-trifluoroethanol. aReaction conditions: $2 \mathbf{2 a}(0.10 \mathrm{mmol}), \mathbf{4}(0.11 \mathrm{mmol}), \mathbf{1}(0.0050 \mathrm{mmol}), \mathrm{HOAC}$ $(0.40 \mathrm{mmol})$, base $(0.20 \mathrm{mmol})$ in solvent $(0.48 \mathrm{~mL})$ and $\mathrm{H}_{2} \mathrm{O}(0.12 \mathrm{~mL})$ at $20^{\circ} \mathrm{C}$ for $48 \mathrm{~h}$ unless otherwise stated. The reaction mixtures were then treated with di-tert-butyl dicarbonate $(0.30 \mathrm{mmol})$ at $\mathrm{rt}$ for $3 \mathrm{~h}$. b Isolated yields based on $\alpha$-keto amide $\mathbf{2 a}$. ${ }^{\mathrm{C}}$ The ee values were determined by HPLC

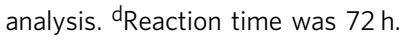

1b (5 mol\%), (R)-1b (5 mol\%), and achiral pyridoxamine 7 (20 mol $\%)$ as the catalyst. The corresponding peptides were formed with $S$ configurations of the newly generated chiral centers from catalyst $(R)-\mathbf{1 b}$ and $R$ configurations from $(S)-\mathbf{1 b}$. The chiral pyridoxamine catalyst dominated the stereoselectivity, while the chiral groups on the amino acid residues of $\alpha$-keto amides throwed little influence on the diastereomeric induction probably due to being far away from the reaction centers as well as the flexibility of the skeletons of the $\alpha$ keto amides. No matter which configuration of the catalyst $\mathbf{1} \mathbf{b}$ was applied, excellent diastereoselectivities were always obtained, even for $\mathbf{a}$-keto amides (for $\mathbf{3 n}$ and 3aa) with a nearby bulky chiral amino acid residue and for those that displayed obvious substrateinduction on diastereoselectivity in 7-catalyzed non-asymmetric transamination $(5: 95 \mathrm{dr}$ for $\mathbf{3 r}$ and 19:81 dr for 3x). For a-keto amide $2 \mathbf{y}$ bearing two nearby chiral centers, a pair of diastereomers $(R, R, S)$-3y and $(R, S, S)-3 y$ were respectively obtained in good yields with high enantiopurities by using $(S)-\mathbf{1 b}$ and $(R)-\mathbf{1 b}$ as the catalyst. The absolute configurations of the newly generated chiral centers of peptides 3 were assigned by analog, based on the X-ray analysis of 3d, $3 \mathbf{~ m}$, and 3r (also see Supplementary Figs. 1-3 in SI).

Synthetic applications. Divergent extending an additional amino acid unit from a central peptide is of great interest for peptide drug screening and bioactivity studies. The synthesis would be difficult when the extended unit is a commercially unavailable unnatural amino acid. The transamination process provides an efficient strategy for the amino acid extending. For example, starting from the benzyl ester of protease inhibitor Ubenimex $(8)^{65}$, condensation with $\alpha$-keto acids and subsequent asymmetric transamination afforded a variety of enantiopure peptides 3ae-ai with one more amino acid residue extended (Fig. 5a). The 


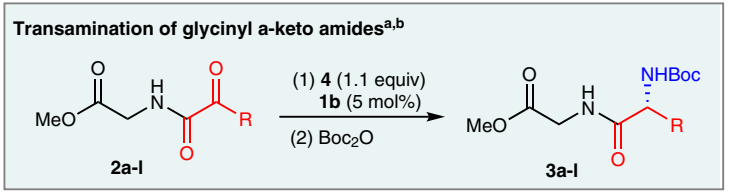

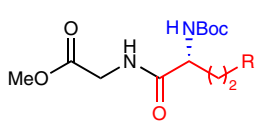

(S)-1b: $3 a(R=P h), 88 \%, 98 \%$ ee (S)-1b: $3 \mathbf{b}\left(\mathrm{R}=n-\mathrm{C}_{5} \mathrm{H}_{13}\right), 82 \%, 96 \%$ ee

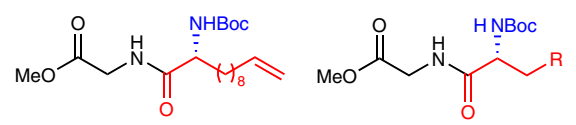

(S)- 1 b: $\mathbf{3 c}, 73 \%, 98 \%$ ee

(S)-1b: $\mathbf{3 d}\left(\mathrm{R}={ }^{i} \mathrm{Pr}\right), 70 \%, 94 \%$ ee (S)-1b: $3 \mathbf{e}(\mathrm{R}=\mathrm{Cy}), 82 \%, 96 \%$ ee

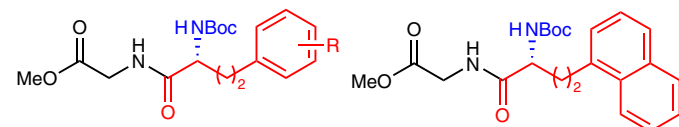

(S)-1b: $\mathbf{3 f}(\mathrm{R}=2-\mathrm{Br}), 72 \%, 97 \%$ ee (S) $-1 \mathrm{~b}: 3 \mathbf{g}\left(\mathrm{R}=4-\mathrm{CF}_{3}\right), 74 \%, 94 \%$ ee (S)-1b: $3 \mathbf{h}\left[\mathrm{R}=3,4-(\mathrm{OMe})_{2}\right], 77 \%, 95 \%$ ee
(S)-1b: $\mathbf{3 i}, 78 \%, 96 \%$ ee<smiles>COC(=O)CNC(=O)C(NCF)[N+](=O)[O-]</smiles>

(S)-1b: $\mathbf{3 j}(\mathrm{R}=\mathrm{Br}), 94 \%, 95 \%$ ee (S) -1 b: $3 \mathbf{k}(R=$ OTBDPS), $86 \%, 94 \%$ ee<smiles>CC(C)=CCCC(C)C[C@H](N)C(=O)NCC(=O)O</smiles>

(R)-1b: $\mathbf{3} \mathbf{l}, 82 \%, 98: 2 \mathrm{dr}$

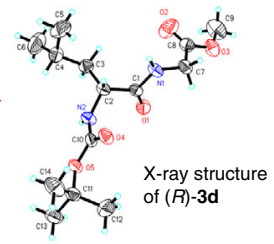

Transamination of a-keto amides of chiral amino acid esters $\mathrm{s}^{\mathrm{a}, \mathrm{b}}$

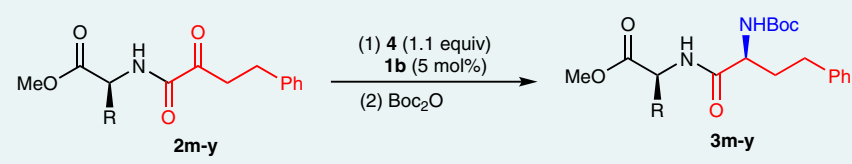<smiles>CC[n+]1cc(COc2ccccc2)c(CN)c(O)c1C</smiles><smiles>COC(=O)[C@H](NC(=O)C(CCc1ccccc1)NC(=O)OCc1ccccc1)C(C)C</smiles>

(S)-1b: $(R, R)-3 \mathbf{n}, 90 \%, 2: 98 d r$ (R)-1b: $(R, S)-3 \mathbf{n}, 81 \%, 97: 3 \mathrm{dr}$ $7(20 \mathrm{~mol} \%)^{\mathrm{c}}$ : $3 \mathrm{n}, 86 \%, 54: 46 \mathrm{dr}$<smiles>COC(=O)[C@H](Cc1ccccc1)NC(=O)C(CCc1ccccc1)NC(=O)OCc1ccccc1</smiles>

(S)-1b: $(S, R)-3 \mathbf{r}, 82 \%, 2: 98 \mathrm{dr}$ (R)-1b: (S,S)-3r, 65\%, 99:1 dr $7(20 \mathrm{~mol} \%)^{\mathrm{c}}$ : $3 \mathbf{r}, 48 \%, 5: 95 \mathrm{dr}$<smiles>COC(=O)[C@H](CC(N)=O)NC(=O)C(CCc1ccccc1)NC(C)(C)C</smiles>

(S)-1b: $(S, R)-3 \mathbf{v}, 77 \%, 3: 97 \mathrm{dr}$ (R)-1b: (S,S)-3v, 67\%, 98:2 dr $7(20 \mathrm{~mol} \%)^{\mathrm{c}}$ : 3v, 62\%, 62:38 dr<smiles>CC[C@H](C)[C@H](NC(=O)[C@H](CCc1ccccc1)NC(=O)OCc1ccccc1)C(=O)OC</smiles>

(R)-1b: 3o, 93\%, 97:3 dr<smiles>COC(=O)[C@H](NC(=O)[C@@H](CCc1ccccc1)NC(=O)OCc1ccccc1)C(C)(C)C</smiles>

(R)-1b: 3p, 80\%, 97:3 dr<smiles>COC(=O)[C@H](CCSC)NC(=O)[C@H](CCc1ccccc1)NC(=O)OCc1ccccc1</smiles>

(R)-1b: 3q, $80 \%, 97: 3 \mathrm{dr}$<smiles>COC(=O)[C@H](C)NC(=O)C(CCc1ccccc1)=NC(=O)OCc1ccccc1</smiles>

(S)-1b: (S,R)-3m, 83\%, 2:98 dr (R)-1b: (S,S)-3m, 84\%, 97:3 dr $7(20 \text { mol\% })^{\mathrm{c}}$ : 3m, $90 \%, 36: 64 \mathrm{dr}$<smiles>COC(=O)[C@H](CCPc1ccccc1)NC(=O)[C@H](CCc1ccccc1)NC(=O)[C@H](Cc1ccc(O)cc1)NC(=O)[C@H](Cc1c[nH]c2ccccc12)C(=O)OC</smiles>

X-ray structure of $(S, R)-3 \mathbf{r}$

(S)-1b: $3 \mathbf{s}, 81 \%, 2: 98 d r$ (S)-1b: 3t, 77\%, 3:97 dr (R)-1b: $3 \mathbf{u}, 84 \%, 97: 3 \mathrm{dr}$<smiles>COC(=O)[C@H](CCCC(=O)OC(C)(C)C)NC(=O)C(CCc1ccccc1)NC(=O)OC(C)(C)C</smiles>

(S)-1b: $(S, R)-3 \mathbf{w}, 88 \%, 1: 99 \mathrm{dr}$ (R)-1b: $(S, S)-3 \mathbf{w}, 87 \%, 98: 2 \mathrm{dr}$ $7(20 \mathrm{~mol} \%)^{\mathrm{c}}: 3 \mathrm{w}, 25 \%, 44: 56 \mathrm{dr}$<smiles>COC(=O)[C@H](CCNNC(=NC(=O)OC(C)(C)C)NC(=O)OCc1ccccc1)NC(=O)C(CCc1ccccc1)NC(C)(C)C</smiles>

(S)-1b: $(S, R)-3 \mathbf{x}, 56 \%, 2: 98 \mathrm{dr}$

(R)-1b: $(S, S)-3 \mathbf{x}, 57 \%, 97: 3 \mathrm{dr}$ $7(20 \mathrm{~mol} \%)^{\mathrm{c}}: 3 \mathbf{x}, 48 \%, 19: 81 \mathrm{dr}$<smiles>COC(=O)NC(C[C@@H](C)CCC=C(C)C)C(=O)N[C@@H](C(=O)OC)C(C)C</smiles>

(S)-1b: (R,R,S)-3y, 72\%, 3.97 dr (R)-1b: $(R, S, S)-3 \mathbf{y}, 75 \%, 99: 1 \mathrm{dr}$ $7(20 \mathrm{~mol} \%)^{\mathrm{C}}$ : 3y, 57\%, 69:31 dr

Transamination of peptidyl a-keto amides ${ }^{a}$

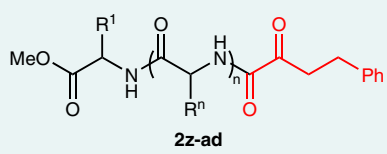

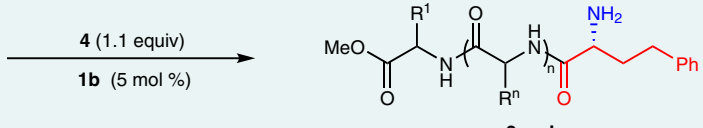

3z-ad<smiles>COC(=O)[C@H](Cc1ccccc1)NC(=O)[C@H](NC(=O)[C@H](N)CCc1ccccc1)C(C)C</smiles>

(R)-1b: 3z, 77\%, 99:1 dr

(S)

(S)-1b: (S,S,R)-3aa, $80 \%, 3: 97 \mathrm{dr}$ (R)-1b: $(S, S, S)-3$ aaa, $87 \%, 96: 4 \mathrm{dr}$ $7(20 \mathrm{~mol} \%)^{\mathrm{c}}:$ 3aa, $99 \%, 50: 50 \mathrm{dr}$<smiles>COC(=O)[C@H](NC(=O)[C@H](CCN)NC(=O)[C@H](N)CCP)C(C)C</smiles>

(S)-1b: $(R, S, R)-3 \mathbf{a b}, 60 \%, 1: 99 \mathrm{dr}$ (R)-1b: $(R, S, S)-3 \mathbf{a b}, 65 \%, 99: 1 \mathrm{dr}$

$7(20 \mathrm{~mol} \%)^{\mathrm{c}}$ : 3ab, 32\%, 43:57 dr<smiles>CC[C@H](C)[C@H](NC(=O)[C@@H](N)CCc1ccccc1)C(=O)N[C@@H](CCSC)C(=O)N[C@H](C(=O)OC)C(C)C</smiles>

(S)-1b: 3ac, 72\%, 2:98 dr<smiles>CC[C@H](C)[C@H](NC(=O)[C@@H]1CCCN1C(=O)[C@@H](NC(=O)[C@H](N)CCc1ccccc1)[C@@H](C)CC)C(=O)OC</smiles>

(S)-1b: 3ad, 64\%, 3:97 dr

Fig. 4 Asymmetric biomimetic transamination of $\boldsymbol{\alpha}$-keto amides. TBDPS = tert-butyldiphenylsilyl. aReaction conditions: 2 (0.10 mmol), 4 (0.11 mmol), $1 \mathbf{b}$ $(0.0050 \mathrm{mmol}), \mathrm{HOAc}(0.40 \mathrm{mmol}), \mathrm{Na}_{2} \mathrm{HPO}_{4}$ or $\mathrm{KOAc}(0.20 \mathrm{mmol})$ in $\mathrm{CF}_{3} \mathrm{CH}_{2} \mathrm{OH}$ or $\mathrm{MeOH}(0.48 \mathrm{~mL})$ and $\mathrm{H}_{2} \mathrm{O}(0.12 \mathrm{~mL})$ for 48 or $72 \mathrm{~h}$ unless otherwise stated (See SI). For $\mathbf{3} \mathbf{m}-\mathbf{y}$, the reactions were carried out in a double scale. Isolated yields were based on $\alpha$-keto amides $\mathbf{2}$. The ee and dr values

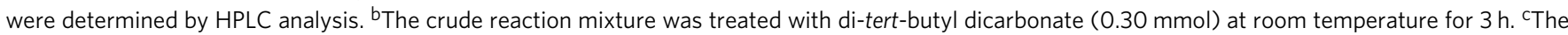
reaction was carried out in a double scale with $7(0.040 \mathrm{mmol}, 20 \mathrm{~mol} \%)$ at $50^{\circ} \mathrm{C}$ for $72 \mathrm{~h}$.

unprotected $\mathrm{OH}$ group remained untouched during the condensation and transamination.

Based on the "condensation-transamination" process, a new strategy for the synthesis of peptides also can be developed. As illustrated in Fig. 5b, the methyl ester of DPP-IV inhibitor Diprotin A (10) ${ }^{66}$ underwent condensation with a-keto acid 9a and subsequent asymmetric transamination, forming tetrapeptide 3ad with excellent diastereoselectivity. Repeating the reaction sequence two more times afforded hexapeptide 3ak with high enantiopurity. The chirality of the extended amino acid residues was established along with the transamination process. The protocol is especially attractive for the synthesis of peptides made 
a Divergent synthesis of peptides

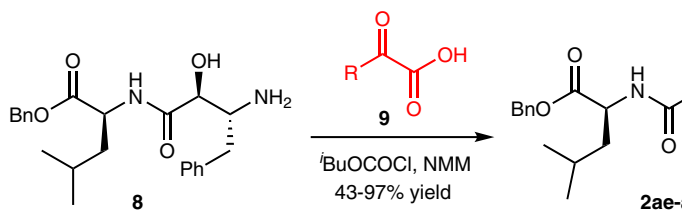

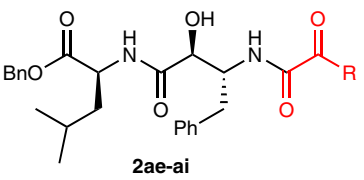
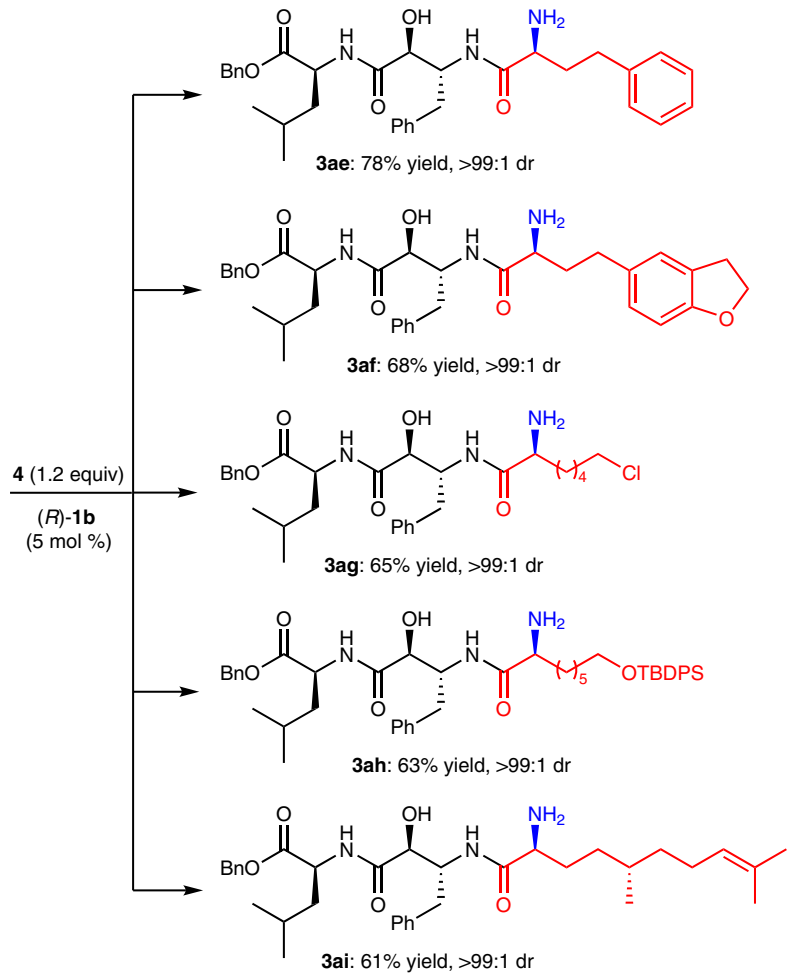

b Synthesis of peptides via successive transamination<smiles>CC[C@H](C)[C@H](N)C(=O)N1CCC[C@H]1C(=O)N[C@H](C(=O)OC)[C@@H](C)CC</smiles>

10

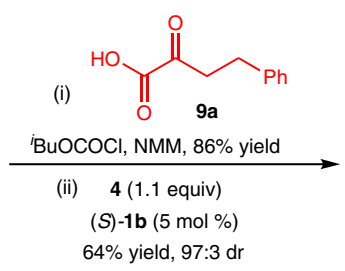

$64 \%$ yield, $97: 3 \mathrm{~d}$<smiles>CCC(C)[C@H](NC(=O)[C@@H]1CCCN1C(=O)[C@@H](NC(=O)[C@H](N)CCc1ccccc1)C(C)CC)C(C)=O</smiles>

(i)<smiles>O=C(O)C(=O)CCl</smiles>

\begin{tabular}{cc} 
EDCl, HOBt, $47 \%$ yield \\
\hline (ii) $4(1.1$ equiv) \\
(S) $-1 \mathbf{b}(5 \mathrm{~mol} \%)$ \\
$52 \%$ yield, $99: 1 \mathrm{dr}$
\end{tabular}<smiles>CCC(C)[C@H](NC(=O)[C@@H]1CCCN1C(=O)[C@@H](NC(=O)C(CCc1ccccc1)NC(=O)[C@@H](NC(=O)[C@H](N)CC1CCCCC1)[Al]CCl)C(C)CC)C(=O)OC</smiles>

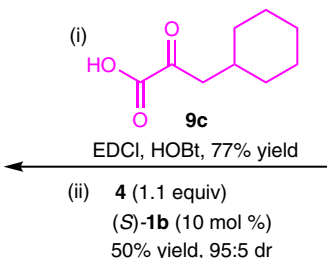<smiles>CC[C@H](C)[C@H](C)C(=O)OC</smiles><smiles>CCC(C)C(I)C(=O)N1CCCC1C(N)=O</smiles><smiles>CCC(=O)C(NC(=O)C(CCc1ccccc1)NC(=O)C(N)C=CCl)C(C)CC</smiles>

Fig. 5 Synthetic applications. a Divergent synthesis of peptides. $N M M=N$-methylmorpholine. $\mathbf{b}$ Synthesis of peptides via successive transamination. $\mathrm{EDCl}=1$-(3-dimethylaminopropyl)-3-ethylcarbodiimide hydrochloride. HOBt $=$ 1-hydroxybenzotriazole.

of unnatural amino acids, since it doesn't need great efforts to make $\mathrm{NH}_{2}$-protected chiral unnatural amino acids before the amide bond formation.

Reaction mechanism. A plausible mechanism was proposed for

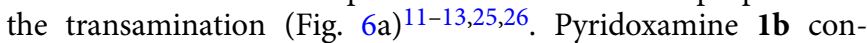
denses with $a$-keto amide 2 to form ketimine 11, which undergoes asymmetric 1,3-proton shift to aldimine 13 under the assistance of the amine side $\operatorname{arm}^{46-50}$. Hydrolysis of aldimine $\mathbf{1 3}$ releases peptide 3 and generates the pydridoxal, which is in situ converted into iminium 14 via intramolecular condensation. The iminium 14 then undergoes decarboxylative transamination with the amine source diphenylglycine (4) back to pyridoxamine catalyst $\mathbf{1 b}^{25,26,63}$, completing a catalytic cycle.

As expected, $\mathrm{N}$-quaternization of the pyridine ring of the chiral pyridoxamines resulted in higher catalytic activity and better enantioselectivity for the asymmetric transamination (Fig. 6b, $\mathbf{1 b}$ vs $\mathbf{1 g}$ ). The stronger electron-withdrawing property makes the benzylic $\mathrm{C}-\mathrm{H}$ of ketimine $\mathbf{1 1}$ more acidic and also stabilizes the corresponding delocalized carbanion 12 better ${ }^{54-58,67-69}$, thus favoring the 1,3-proton shift and accelerating the transamination process. The control experiment confirmed the amazing effect of the amine side arm again (Fig. 6b, 1b vs 1f). Introducing an acetyl group onto the nitrogen to eliminate the basicity of the amine on the side arm led to marked decreases in activity and enantioselectivity. The amine side arm not only promotes the 1,3-proton shift by acting as an intramolecular base to deprotonate the benzylic C-H of ketimine $\mathbf{1 1}$ (Fig. 6a) but also helps to orient the a-keto amide by hydrogen bonding with the carbonyl oxygen of the amide group (Fig. 6c), resulting in improved activity and stereoselectivity ${ }^{48-50}$. Protonation of the delocalized carbanion 12 occurs at $\alpha$-position of the amide group from the up side of the pyridine ring away from the amine side $\operatorname{arm}^{26,46,47}$, to form the newly generated chiral center with $S$ configuration from catalyst $(R)-\mathbf{1 b}$. 
a

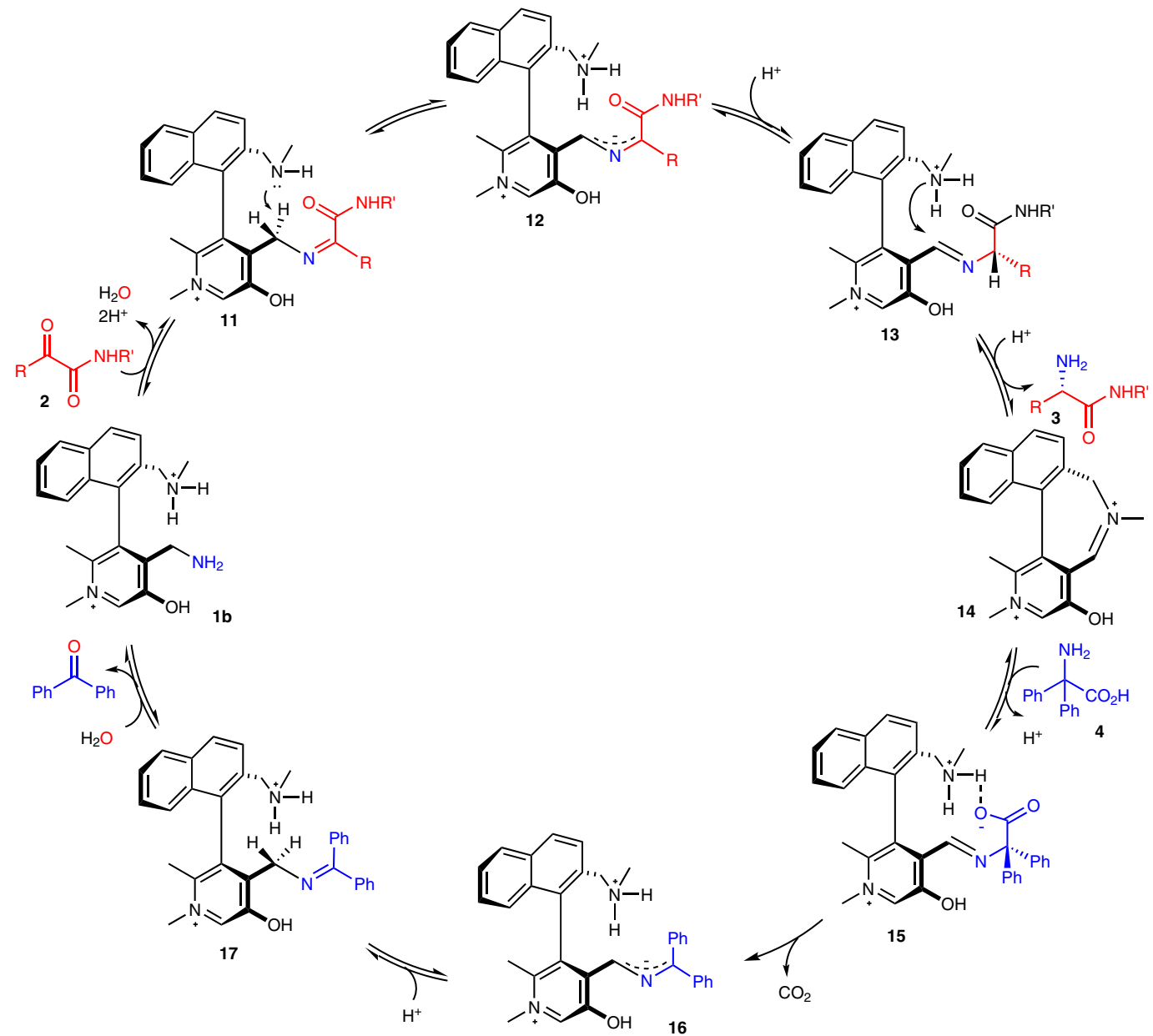

b<smiles>COC(=O)CNC(=O)C(=O)CCc1ccccc1</smiles>

(1) 4 (1.1 equiv), 1 ( $5 \mathrm{~mol} \%$ ), $20^{\circ} \mathrm{C}$<smiles>COC(=O)CNC(=O)[C@H](CCc1ccccc1)NC(=O)O</smiles><smiles>CNCc1ccc2ccccc2c1-c1c(CN)c(O)c[n+](C)c1C</smiles>

1b: $88 \%$ yield, $98 \%$ ee

(2) $\mathrm{Boc}_{2} \mathrm{O}$

3a<smiles>CC(=O)N(C)Cc1ccc2ccccc2c1-c1c(CN)c(O)c[n+](C)c1C</smiles>

1f: $24 \%$ yield, $-30 \%$ ee

c

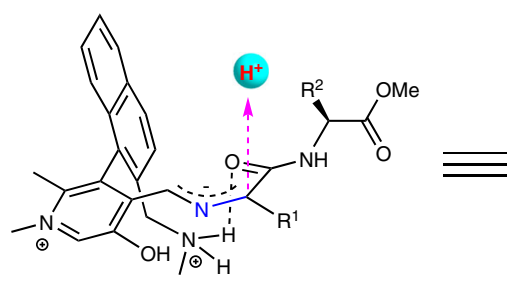

12<smiles>CNCc1ccc2ccccc2c1-c1c(C)ncc(O)c1CN</smiles>

1g: $57 \%$ yield, $92 \%$ ee

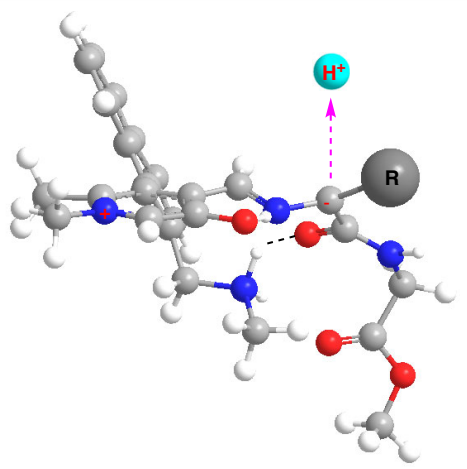

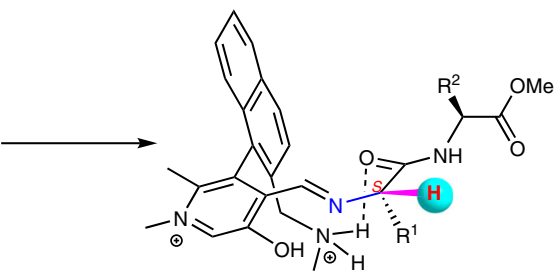

13

Fig. 6 Reaction mechanism. a Proposed reaction pathway. b Comparison of catalysts. c Proposed transition state for the asymmetric 1,3-proton shift.

\section{Discussion}

In summary, based on the concept of multiple imitation of transaminases, we have developed $\mathrm{N}$-quaternized axially chiral pyridoxamines 1 containing an amine side arm. With pyridoxamine $\mathbf{1 b}$ as the catalyst, challenging substrates a-keto amides were successfully transaminated to peptides in good yields with excellent enantio- and diastereoselectivities. The catalyst dominated the diastereoselective control for the transamination of chiral a-keto amides. Thus, a pair of diastereomeric peptides could be respectively obtained with high enantiopurities by 
switching the configuration of the pyridoxamine catalyst. The strong electron-withdrawing property of the N-quaternized pyridine ring together with the cooperative catalysis of the amine side arm account for the increased catalytic activity and selectivity of the pyridoxamine $\mathbf{1 b}$ in the transamination. The reaction can provide an efficient strategy for divergent and successive extension of peptides via condensation-transamination reaction sequence, which is especially attractive for the synthesis of peptides made of unnatural amino acids.

\section{Methods}

General procedure for the asymmetric biomimetic transamination Reaction (Fig. 4). A mixture of a-keto amide $2(0.10 \mathrm{mmol})$, chiral pyridoxamine $\mathbf{1 b}$ (0.0050 mmol), 2,2-diphenylglycine (4) $(0.11 \mathrm{mmol}), \mathrm{HOAc}(0.40 \mathrm{mmol})$, $\mathrm{Na}_{2} \mathrm{HPO}_{4}$ or KOAc $(0.20 \mathrm{mmol}), \mathrm{CF}_{3} \mathrm{CH}_{2} \mathrm{OH}$ or $\mathrm{MeOH}(0.48 \mathrm{~mL})$, and $\mathrm{H}_{2} \mathrm{O}$ $(0.12 \mathrm{~mL})$ was stirred at $16-25^{\circ} \mathrm{C}$ for the specified time. For glycinyl $\alpha$-keto amides (for 3a-1) and a-keto phenylbutanamides of amino acid esters (for $\mathbf{3 m}-\mathbf{y}$ ), the crude reaction mixtures were treated with di-tert-butyl dicarbonate $(0.3 \mathrm{mmol})$ at room temperature for $3 \mathrm{~h}$ after the transamination was completed, then concentrated via rotary evaporator to remove most of the solvent and isolated by column chromatography on silica gel with a mixed solvent ethyl acetate and petroleum ether as the eluant to give the products $N$-Boc-protected dipeptides 3a-y. For Peptidyl $\alpha$ keto amides (for $\mathbf{3 z - a d}$ ), the reaction mixtures were submitted to concentration via rotary evaporator to remove most of the solvent and then isolated by column chromatography on silica gel with a mixed solvent of dichloromethane, methanol and ammonia solution in ethanol $(2.9 \mathrm{M})$ as the eluant to give the transamination products tripeptides $\mathbf{3 z}$-aa and tetrapeptides $\mathbf{3 a b}$-ad without $\mathrm{NH}_{2}$-protection. The ee and dr values of $\mathbf{3 a - a c}$ were determined by HPLC analysis.

\section{Data availability}

The authors declare that the data supporting the findings of this study are available within the article and Supplementary Information file, or from the corresponding author upon reasonable request. For the experimental procedures, characterization data, and NMR spectra along with HPLC chromatograms, see Supplementary Information. The $\mathrm{X}$-ray crystallographic coordinates for structures reported in this study have been deposited at the Cambridge Crystallographic Data Centre (CCDC), under deposition numbers of CCDC 2036531 (3d), CCDC 2036532 (the cyclized derivative of $\mathbf{3} \mathbf{~ m}$ ), and CCDC 2036529 (3r). These data can be obtained free of charge from The Cambridge Crystallographic Data Centre via https://www.ccdc. cam.ac.uk/structures/.

Received: 15 December 2020; Accepted: 11 August 2021; Published online: 30 August 2021

\section{References}

1. Henninot, A., Collins, J. C. \& Nuss, J. M. The current state of peptide drug discovery: back to the future? J. Med. Chem. 61, 1382-1414 (2018).

2. Lau, J. L. \& Dunn, M. K. Therapeutic peptides: historical perspectives, current development trends, and future directions. Bioorg. Med. Chem. 26, 2700-2707 (2018).

3. Vlieghe, P., Lisowski, V., Martinez, J. \& Khrestchatisky, M. Synthetic therapeutic peptides: science and market. Drug Discov. Today 15, 40-56 (2010).

4. Piliero, P. J. Atazanavir: A Novel HIV-1 Protease Inhibitor. Expert Opin. Inv. Drugs 11, 1295-1301 (2002).

5. Ricci, F. et al. Intermediate dose Ara-C followed by G-CSF: an effective and predictable mobilization regimen in hematological malignancies. Blood 110, 3290-3290 (2007).

6. BEER, T. M., GARZOTTO, M., EILERS, K. M. \& LEMMON, D. Phase II study of abarelix depot for androgen independent prostate cancer progression during gonadotropin-releasing hormone agonist therapy. J. Urol. 169, 1738-1741 (2003).

7. Humphrey, J. M. \& Chamberlin, A. R. Chemical synthesis of natural product peptides: coupling methods for the incorporation of noncoded amino acids into peptides. Chem. Rev. 97, 2243-2266 (1997).

8. El-Faham, A. \& Albericio, F. Peptide coupling reagents, more than a letter soup. Chem. Rev. 111, 6557-6602 (2011).

9. Taylor, P. P., Pantaleone, D. P., Senkpeil, R. F. \& Fotheringham, I. G. Novel biosynthetic approaches to the production of unnatural amino acids using transaminases. Trends Biotechnol. 16, 412-418 (1998).

10. Fuchs, M., Farnberger, J. E. \& Kroutil, W. The industrial age of biocatalytic transamination. Eur. J. Org. Chem. 2015, 6965-6982 (2015).
11. Metzler, D. E., Ikawa, M. \& Snell, E. E. A general mechanism for vitamin $\mathrm{B}_{6}{ }^{-}$ catalyzed reactions. J. Am. Chem. Soc. 76, 648-652 (1954).

12. Ayling, J. \& Snell, E. E. Mechanism of action of pyridoxamine pyruvate transaminase. Biochemistry 7, 1616-1625 (1968).

13. Liao, R.-Z., Ding, W.-J., Yu, J.-G., Fang, W.-H. \& Liu, R.-Z. Theoretical studies on pyridoxal $5^{\prime}$-phosphate-dependent transamination of $\alpha$-amino acids. $J$. Comput. Chem. 29, 1919-1929 (2008).

14. Breslow, R. Biomimetic chemistry: biology as an inspiration. J. Biol. Chem 284, 1337-1342 (2009).

15. Breslow, R. Biomimetic chemistry and artificial enzymes: catalysis by design. Acc. Chem. Res. 28, 146-153 (1995).

16. Xie, Y., Pan, H., Liu, M., Xiao, X. \& Shi, Y. Progress in asymmetric biomimetic transamination of carbonyl compounds. Chem. Soc. Rev. 44, 1740-1748 (2015).

17. Chen, J., Liu, Y. E., Gong, X., Shi, L. \& Zhao, B. Biomimetic chiral pyridoxal and pyridoxamine catalysts. Chin. J. Chem. 37, 103-112 (2019).

18. Kuzuhara, H., Komatsu, T. \& Emoto, S. Synthesis of a chiral pyridoxamine analog and nonenzymatic stereoselective transamination. Tetrahedron Lett. 19, 3563-3566 (1978).

19. Breslow, R., Hammond, M. \& Lauer, M. Selective transamination and optical induction by a $\beta$-cyclodextrin-pyridoxamine artificial enzyme. J. Am. Chem. Soc. 102, 421-422 (1980).

20. Zimmerman, S. C. \& Breslow, R. Asymmetric synthesis of amino acids by pyridoxamine enzyme analogs utilizing general base-acid catalysis. J. Am. Chem. Soc. 106, 1490-1491 (1984).

21. Wei, S., Wang, J., Venhuizen, S., Skouta, R. \& Breslow, R. Dendrimers in solution can have their remote catalytic groups folded back into the core: enantioselective transaminations by dendritic enzyme mimics-II. Bioorg. Med. Chem. Lett. 19, 5543-5546 (2009).

22. Kikuchi, J.-i, Zhang, Z.-Y. \& Murakami, Y. Enantioselective catalysis by a supramolecular bilayer membrane as an artificial aminotransferase. stereochemical roles of an L-lysine residue and L-phenylalanine at the reaction site. J. Am. Chem. Soc. 117, 5383-5384 (1995).

23. Kuang, H. \& Distefano, M. D. Catalytic enantioselective reductive amination in a host-guest system based on a protein cavity. J. Am. Chem. Soc. 120, 1072-1073 (1998).

24. Svenson, J., Zheng, N. \& Nicholls, I. A. A molecularly imprinted polymerbased synthetic transaminase. J. Am. Chem. Soc. 126, 8554-8560 (2004).

25. Shi, L. et al. Chiral pyridoxal-catalyzed asymmetric biomimetic transamination of $\alpha$-keto acids. Org. Lett. 17, 5784-5787 (2015).

26. Liu, Y. E. et al. Enzyme-inspired axially chiral pyridoxamines armed with a cooperative lateral amine chain for enantioselective biomimetic transamination. J. Am. Chem. Soc. 138, 10730-10733 (2016).

27. Bernauer, K., Deschenaux, R. \& Taura, T. Stereoselectivity in reactions of metal complexes VII. Asymmetric synthesis of amino acids by metal ionpromoted transamination. Helv. Chim. Acta 66, 2049-2058 (1983).

28. Soloshonok, V. A., Kirilenko, A. G., Galushko, S. V. \& Kukhar, V. P. Catalytic asymmetric synthesis of $\beta$-fluoroalkyl- $\beta$-amino acids via biomimetic $[1,3]$ proton shift reaction. Tetrahedron Lett. 35, 5063-5064 (1994).

29. Willems, J. G. H., de Vries, J. G., Nolte, R. J. M. \& Zwanenburg, B. Asymmetric imine isomerisation in the enantioselective synthesis of chiral amines from prochiral ketones. Tetrahedron Lett. 36, 3917-3920 (1995).

30. Hjelmencrantz, A. \& Berg, U. New approach to biomimetic transamination using bifunctional [1,3]-proton transfer catalysis in thioxanthenyl dioxide imines. J. Org. Chem. 67, 3585-3594 (2002).

31. Knudsen, K. R., Bachmann, S. \& Jørgensen, K. A. Catalytic enantioselective transaminiation of $\alpha$-keto esters: an organic approach to enzymatic reactions. Chem. Commun. 20, 2602-2603 (2003).

32. Xiao, X., Xie, Y., Su, C., Liu, M. \& Shi, Y. Organocatalytic asymmetric biomimetic transamination: from $\alpha$-keto esters to optically active $\alpha$-amino acid derivatives. J. Am. Chem. Soc. 133, 12914-12917 (2011).

33. Wu, Y. \& Deng, L. Asymmetric synthesis of trifluoromethylated amines via catalytic enantioselective isomerization of imines. J. Am. Chem. Soc. 134, 14334-14337 (2012)

34. Xie, Y., Pan, H., Xiao, X., Li, S. \& Shi, Y. Organocatalytic asymmetric biomimetic transamination of aromatic ketone to optically active amine. Org. Biomol. Chem. 10, 8960-8962 (2012).

35. Zhou, X., Wu, Y. \& Deng, L. Cinchonium betaines as efficient catalysts for asymmetric proton transfer catalysis: the development of a practical enantioselective isomerization of trifluoromethyl imines. J. Am. Chem. Soc. 138, 12297-12302 (2016).

36. Kang, Q.-K., Selvakumar, S. \& Maruoka, K. Asymmetric synthesis of $\alpha$-amino acids by organocatalytic biomimetic transamination. Org. Lett. 21, 2294-2297 (2019).

37. Herbst, R. M. \& Shemin, D. The synthesis of peptides by transamination. J. Biol. Chem. 147, 541-547 (1943). 
38. Lee, S. H., Kyung, H., Yokota, R., Goto, T. \& Oe, T. N-terminal a-ketoamide peptides: formation and transamination. Chem. Res. Toxicol. 27, 637-648 (2014).

39. Cennamo, C., Carafoli, B. \& Bonetti, E. P. Non-enzymatic transamination between peptides and pyridoxal. Isolation of the 2,4-dinitrophenylhydrazones of some ketopeptides. J. Am. Chem. Soc. 78, 3523-3527 (1956).

40. Dixon, H. Transamination of peptides. Biochem. J. 92, 661-666 (1964).

41. Papanikos, A., Rademann, J. \& Meldal, M. a-ketocarbonyl peptides: a general approach to reactive resin-bound intermediates in the synthesis of peptide isosteres for protease inhibitor screening on solid support. J. Am. Chem. Soc. 123, 2176-2181 (2001).

42. Gilmore, J. M., Scheck, R. A., Esser-Kahn, A. P., Joshi, N. S. \& Francis, M. B. $\mathrm{N}$-terminal protein modification through a biomimetic transamination reaction. Angew. Chem. Int. Ed. 45, 5307-5311 (2006).

43. Scheck, R. A., Dedeo, M. T., Iavarone, A. T. \& Francis, M. B. Optimization of a biomimetic transamination reaction. J. Am. Chem. Soc. 130, 11762-11770 (2008).

44. Witus, L. S. et al. Site-specific protein transamination using Nmethylpyridinium-4-carboxaldehyde. J. Am. Chem. Soc. 135, 17223-17229 (2013).

45. Palla, K. S., Witus, L. S., Mackenzie, K. J., Netirojjanakul, C. \& Francis, M. B. Optimization and expansion of a site-selective N-methylpyridinium-4carboxaldehyde-mediated transamination for bacterially expressed proteins. J. Am. Chem. Soc. 137, 1123-1129 (2015).

46. Yoshimura, T., Jhee, K.-H. \& Soda, K. Stereospecificity for the hydrogen transfer and molecular evolution of pyridoxal enzymes. Biosci. Biotechnol. Biochem. 60, 181-187 (1996).

47. Soda, K., Yoshimura, T. \& Esaki, N. Stereospecificity for the hydrogen transfer of pyridoxal enzyme reactions. Chem. Rec. 1, 373-384 (2001).

48. Kirsch, J. F. et al. Mechanism of action of aspartate aminotransferase proposed on the basis of its spatial structure. J. Mol. Biol. 174, 497-525 (1984).

49. Kochhar, S., Finlayson, W. L., Kirsch, J. F. \& Christen, P. The stereospecific labilization of the C-4' pro-S hydrogen of pyridoxamine 5'-phosphate is abolished in (Lys258-Ala) aspartate aminotransferase. J. Biol. Chem. 262, 11446-11448 (1987).

50. Malashkevich, V. N. et al. Structural basis for the catalytic activity of aspartate aminotransferase $\mathrm{K} 258 \mathrm{H}$ lacking the pyridoxal 5'-phosphate-binding lysine residue. Biochemistry 34, 405-414 (1995).

51. Adrover, M. et al. Towards a detailed description of pyridoxamine tautomeric species. N. J. Chem. 36, 1751-1761 (2012).

52. Gansow, O. A. \& Holm, R. H. Aqueous solution equilibria of pyridoxamine, pyridoxal, 3-hydroxypyridine-4-aldehyde, and 3-hydroxypyridine-2-aldehyde as studied by proton resonance. Tetrahedron 24, 4477-4487 (1968).

53. Limbach, H.-H. et al. Critical hydrogen bonds and protonation states of pyridoxal 5'-phosphate revealed by NMR. Biochim. Biophys. Acta 1814 1426-1437 (2011).

54. Yano, T., Kuramitsu, S., Tanase, S., Morino, Y. \& Kagamiyama, H. Role of Asp222 in the catalytic mechanism of Escherichia coli aspartate aminotransferase: the amino acid residue which enhances the function of the enzyme-bound coenzyme pyridoxal 5'-phosphate. Biochemistry 31, 5878-5887 (1992).

55. Sharif, S. et al. NMR localization of protons in critical enzyme hydrogen bonds. J. Am. Chem. Soc. 129, 9558-9559 (2007)

56. Griswold, W. R. \& Toney, M. D. Role of the pyridine nitrogen in pyridoxal $5^{\prime}$ phosphate catalysis: activity of three classes of plp enzymes reconstituted with deazapyridoxal 5'-phosphate. J. Am. Chem. Soc. 133, 14823-14830 (2011).

57. Crugeiras, J., Rios, A., Riveiros, E. \& Richard, J. P. Substituent effects on electrophilic catalysis by the carbonyl group: anatomy of the rate acceleration for PLP-catalyzed deprotonation of glycine. J. Am. Chem. Soc. 133, 3173-3183 (2011).

58. Crugeiras, J., Rios, A., Amyes, T. L. \& Richard, J. P. Carbon acidity of the $\alpha-$ pyridinium carbon of a pyridoxamine analog. Org. Biomol. Chem. 3, 2145-2149 (2005).

59. Buckley, T. F. \& Rapoport, H. Mild and simple biomimetic conversion of amines to carbonyl compounds. J. Am. Chem. Soc. 104, 4446-4450 (1982)

60. Chen, J. et al. Carbonyl catalysis enables a biomimetic asymmetric Mannich reaction. Science 360, 1438-1442 (2018).

61. Cheng, A. et al. Efficient Asymmetric Biomimetic Aldol Reaction of Glycinates and Trifluoromethyl Ketones by Carbonyl Catalysis. Angew. Chem. Int. Ed. https://doi.org/10.1002/anie.202104031 (2021).

62. Ma, J. et al. Enantioselective synthesis of pyroglutamic acid esters from glycinate via carbonyl catalysis. Angew. Chem. Int. Ed. 60, 10588-10592 (2021).
63. Liu, L., Zhou, W., Chruma, J. \& Breslow, R. Transamination reactions with multiple turnovers catalyzed by hydrophobic pyridoxamine cofactors in the presence of polyethylenimine polymers. J. Am. Chem. Soc. 126, 8136-8137 (2004).

64. Yamazaki, Y. et al. Acid catalyzed monodehydro-2,5-diketopiperazine formation from N-a-ketoacyl amino acid amides. Tetrahedron 65, 3688-3694 (2009).

65. Yoneda, J. et al. Inhibition of tumor invasion and extracellular matrix degradation by ubenimex (bestatin). Clin. Exp. Metastasis 10, 49-59 (1992).

66. Juillerat-Jeanneret, L. Dipeptidyl peptidase IV and its inhibitors: therapeutics for type 2 diabetes and what else? J. Med. Chem. 57, 2197-2212 (2014).

67. Crugeiras, J., Rios, A., Riveiros, E., Amyes, T. L. \& Richard, J. P. Glycine enolates: the effect of formation of iminium ions to simple ketones on $\alpha$ amino carbon acidity and a comparison with pyridoxal iminium ions. J. Am. Chem. Soc. 130, 2041-2050 (2008).

68. Tang, S., Zhang, X., Sun, J., Niu, D. \& Chruma, J. J. 2-azaallyl anions, 2-azaallyl cations, 2-azaallyl radicals, and azomethine ylides. Chem. Rev. 118, 10393-10457 (2018).

69. Chen, W.-W. \& Zhao, B. Decarboxylative umpolung synthesis of amines from carbonyl compounds. Synlett 31, 1543-1550 (2020).

\section{Acknowledgements}

We are grateful for the generous financial support from the National Natural Science Foundation of China $(21672148,21871181)$, the Shanghai Municipal Education Commission (2019-01-07-00-02-E00029), the Shanghai Municipal Committee of Science and Technology (18ZR1447600, 20JC1416800), “111” Innovation and Talent Recruitment Base on Photochemical and Energy Materials (D18020), and Shanghai Engineering Research Center of Green Energy Chemical Engineering (18DZ2254200).

\section{Author contributions}

B.Z. conceived and directed the project and wrote the paper. W.C and X.Q. conducted most of the experiments including the synthesis of the chiral pyridoxamine catalysts and the development of the asymmetric biomimetic transamination reaction. H.Z. synthesized some pyridoxamine intermediates and several $\alpha$-keto amides for the transamination. B.L. performed some experiments for the catalyst development. J.G. and L.Z synthesized several $a$-keto amides for the transamination. W.C. revised the manuscript and the Supplementary Information.

\section{Competing interests}

The authors declare no competing interests.

\section{Additional information}

Supplementary information The online version contains supplementary material available at https://doi.org/10.1038/s41467-021-25449-y.

Correspondence and requests for materials should be addressed to B.Z.

Peer review information Nature Communications thanks the anonymous reviewer(s) for their contribution to the peer review of this work. Peer reviewer reports are available.

Reprints and permission information is available at http://www.nature.com/reprints

Publisher's note Springer Nature remains neutral with regard to jurisdictional claims in published maps and institutional affiliations.

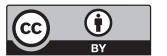

Open Access This article is licensed under a Creative Commons Attribution 4.0 International License, which permits use, sharing, adaptation, distribution and reproduction in any medium or format, as long as you give appropriate credit to the original author(s) and the source, provide a link to the Creative Commons license, and indicate if changes were made. The images or other third party material in this article are included in the article's Creative Commons license, unless indicated otherwise in a credit line to the material. If material is not included in the article's Creative Commons license and your intended use is not permitted by statutory regulation or exceeds the permitted use, you will need to obtain permission directly from the copyright holder. To view a copy of this license, visit http://creativecommons.org/ licenses/by/4.0/

(C) The Author(s) 2021 